NBER WORKING PAPER SERIES

\title{
CRAFTING A CLASS: THE TRADE OFF BETWEEN MERIT SCHOLARSHIPS AND ENROLLING LOWER-INCOME STUDENTS
}

\author{
Ronald G. Ehrenberg \\ Liang Zhang \\ Jared M. Levin \\ Working Paper 11437 \\ http://www.nber.org/papers/w11437
NATIONAL BUREAU OF ECONOMIC RESEARCH
1050 Massachusetts Avenue
Cambridge, MA 02138
June 2005

Ehrenberg is the Irving M. Ives Professor of Industrial and Labor Relations and Economics at Cornell University, Director of the Cornell Higher Education Institute (CHERI) and a research associate at the National Bureau of Economic Research. Zhang is an assistant professor of higher education at the University of Minnesota and a faculty associate at CHERI. Levin is an undergraduate research assistant at CHERI. CHERI is financially supported by the Andrew W. Mellon Foundation, the Atlantic Philanthropies (USA) Inc and the TIAA-CREF Institute and we are grateful to them for their support. However, the views expressed in this paper are entirely our own. The views expressed herein are those of the author(s) and do not necessarily reflect the views of the National Bureau of Economic Research.

(C2005 by Ronald G. Ehrenberg, Liang Zhang, and Jared M. Levin. All rights reserved. Short sections of text, not to exceed two paragraphs, may be quoted without explicit permission provided that full credit, including $(\odot$ notice, is given to the source. 
Crafting a Class: The Trade Off Between Merit Scholarships and Enrolling Lower-Income Students

Ronald G. Ehrenberg, Liang Zhang, and Jared M. Levin

NBER Working Paper No. 11437

June 2005

JEL No. I2, J4

\begin{abstract}
Our paper uses institutional-level panel data to test whether an increase in the number of institutionally funded National Merit Scholarship (NMS) winners at an institution is associated with a reduction in the number of Pell Grant recipients at the institution. We find that, other factors held constant, an increase in the share of institutionally funded NMS winners in an institution's first-year class is associated with a reduction in the share of Pell Grant recipients among the institution's undergraduate student body and that the magnitude of this relationship is larges at the institutions that enroll the greatest number of NMS students.

Ronald G. Ehrenberg

Cornell University

CHERI

256 Ives Hall

Ithaca, NY 14853-3901

and NBER

rge2@cornell.edu

Liang Zhang

Cornell University

1z33@cornell.edu

Jared M. Levin

Cornell University

jm1225@cornell.edu
\end{abstract}




\section{Introduction}

One of the strengths of the American higher education system is its competitive nature. Colleges and universities compete for faculty, for students, for external research funding and on the athletic fields. Given the wide publicity that the U.S. News \& World Reports annual rankings of colleges and universities receives and the importance of student selectivity in these rankings, increasingly American colleges and universities are using merit aid as a vehicle to attract higher test score students and to improve their rankings. ${ }^{1}$

It is well-known that test scores are correlated with students' socio-economic backgrounds. Hence to the extent that colleges are successful in "buying" higher test score students, one should expect that their enrollment of students from families in the lower tails of the family income distribution should decline. However, somewhat surprisingly, there have been no efforts to test if this is occurring.

Our paper presents such a test. While institutional level data on the dollar amounts of merit scholarships offered by colleges and universities are not available, data are available on the number of National Merit Scholarship (henceforth NMS) winners attending an institution on scholarships that have been funded by the institution itself, rather than the National Merit Scholarship Corporation (henceforth NMSC). These institutional scholarships are awarded to high test score students only if they attend the institution. Our research strategy is to estimate if an increase in the number of recipients of these scholarships at an institution is associated with a decline in the number of students from lower and lower middle income families attending the institution, other

\footnotetext{
${ }^{1}$ See, for example, Michael S. McPherson and Morton O. Schapiro (1998, 2002), Elizabeth A. Duffy and Idana Goldberg (1998) and Ronald G. Ehrenberg (forthcoming)
} 
factors held constant. We measure the number of these students by the number of Pell Grant recipients attending the institution.

Section II of our paper briefly describes the National Merit Scholarship and the federal Pell Grant programs. In section III, we describe our analytical approach and section IV presents our empirical findings. Section $V$ provides some brief concluding remarks.

\section{The National Merit Scholarship and Pell Grant Programs ${ }^{2}$}

The National Merit Scholarship Program began in 1955. High school students qualify for awards based upon their scores on the PSAT examination, high school records, letters of recommendation, information about the students' activities and leadership, and personal essays.

Three types of $N M S$ awards exist. The first is a set of scholarships awarded to top students independent of family financial circumstances by the NMSC itself; these awards currently are $\$ 2,500$ scholarships for one year of college and winners are free to choose the institution that they wish to attend. The second is a set of scholarships awarded by corporations to top students who are employees of the corporations, children of employees, residents of a community in which the corporations have operations, or students pursuing college majors or careers in which the corporations have a special interest. These scholarships may be for one year of study or renewable for four years. Again there is no restriction on the college or university that the student may attend.

The final type, and the focus of our attention, is the NMS awards funded by colleges and universities. Finalists in the NMS competition notify the $N M S C$ of their first choice college or university and the NSMC in turn notifies the institution. Each institution that

\footnotetext{
${ }^{2}$ A more detailed discussion of the NMS program is found at www.nationalmerit.org .
} 
offers this type of award makes awards to a subset of the finalists that have indicated that they wish to attend the institution. Crucially, an award is cancelled if the student decides not to attend the institution. Hence, these awards are contingent on attending the institution.

These college and university funded awards are renewable for up to four years of undergraduate study and provide stipends that range from $\$ 500$ to $\$ 2,000$ a year. Awards of this amount pale when compared to the $\$ 30,000$ tuition and fee levels that are now common at the nation's most selective private colleges and universities. However, previous research has indicated that offering a top student a named scholarship enhances the likelihood that a student will attend an institution. ${ }^{3}$ In addition, it is likely that institutions that offer $N M S$ awards offer additional merit aid to students and hence that the dollar amount of the NMS awards likely understates the amount of merit aid that the recipients receive from the institution.

Table 1 provides information on the total number of $N M S$ awards and the number of these awards funded by colleges and universities for selected academic years between 1983 and $2003 .^{4}$ The total number of $N M S$ awards grew from 5,566 in 1983 to 8,244 in 2003. As the third column indicates the percentage of these awards funded by colleges and universities increased from $42.8 \%$ in 1983 to $56.5 \%$ in 1995 and has remained at about that percentage since then.

$N M S$ awards are heavily concentrated among a small number of our nation's over 3,500 colleges and universities. Our econometric research will involve analyzing panel data for the 100 colleges and universities that had the most new NMS winners attending

\footnotetext{
${ }^{3}$ Christopher Avery and Caroline Hoxby (2004)

${ }^{4}$ These data were provided to the authors by the National Merit Scholarship Corporation.
} 
them in 2003. The names of the institutions and their number of NMS winners in 2003 appear in the appendix. ${ }^{5}$

These top 100 institutions enrolled about $84 \%$ of all of the NMS winners in 2003 with somewhat lower percentages in the earlier years. ${ }^{6}$ Many of these institutions are among the small number of colleges and universities that still pursue need blind admissions and need-based financial aid policies and a number of them accordingly offer

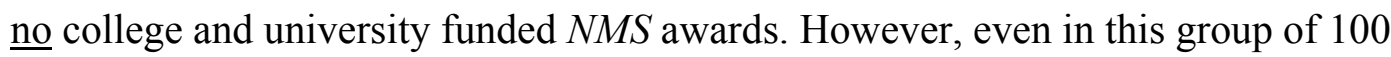
institutions, the percentage of $N M S$ awards that were funded by the institutions themselves rose from $41.5 \%$ in 1983 to about $55.5 \%$ at the turn of the $21^{\text {st }}$ century.

Table 2 provide information for each year during our sample period on the numbers of institution funded and non-institution funded $N M S$ students at these institutions at the $25^{\text {th }}$ percentile, $50^{\text {th }}$ percentile (median), $75^{\text {th }}$ percentile and mean institution in our top 100 sample. The total number of $N M S$ students increases at each point in the distribution; this increase is at least partially due to the way the institutions were selected (top 100 in 2003). What stands out, however, is that virtually all of the growth in the number of $N M S$ winners occurred in the institution funded category. For example, the mean number of institutional funded awards in the sample rose from 17 in 1983 to 37 in 2003 . As late as $1995-96$, the $25^{\text {th }}$ percentile institution (in terms of total number of NMS awards in 2003) offered no institutional funded NMS awards. By 2003-2004, however, the $25^{\text {th }}$ percentile institution in the group offered 12 institutionally funded NMS awards.

Our interest is in how the growth of merit scholarships has influenced the proportion of students from lower and lower middle income families attending selective institutions.

\footnotetext{
${ }^{5}$ There actually are 103 institutions in the sample because of a tie for $100^{\text {th }}$ place.

${ }^{6}$ The lower enrollment shares in earlier years are an artifact of the way the panel was constructed. This occurs because there is some variation in the institutions that appear in the top 100 list from year to year.
} 
While institutional level data on the family income distribution of students are not collected by the U.S. Department of Education, data on the number of Pell Grant recipients at each institution are collected annually.

The Pell Grant program is the largest need-based financial aid program, in the United States; it provided about $\$ 12.6$ billion dollars in funding to 5.1 million undergraduate students in 2003-2004. ${ }^{7}$ Eligibility for Pell Grants for a dependent student is based upon a dependent student's family income and wealth, the number of siblings in college and the expected costs of attending the institution; for independent students eligibility is based upon the income of the student and his or her spouse. ${ }^{8}$ Prior to 1993, awards were also constrained to be less than $60 \%$ of the costs of attending an institution; some students who attended low-cost institutions were excluded from participating in the Pell Grant program for this reason.

Data from the 2002-2003 Title IV/Federal Pell Grant Program End-of-Year Report indicate that in that year $87 \%$ of all Pell Grant recipients at 4-year public institutions came from families with family incomes of $\$ 40,000$ or less; the comparable figure at 4year private institutions was $86.6 \% .{ }^{9}$ Hence the share of Pell Grant recipients among an institution's undergraduate student body is a good proxy for the share of its students coming from lower and lower middle income families. ${ }^{10}$

\footnotetext{
${ }^{7}$ Trends in Student Aid 2004 (2004), tables 1 and 3

${ }^{8}$ Seftor and Turner (2002) indicate that throughout the 1990s, over one-half of Pell Grant recipients were independent students, although this fraction is likely to be much lower in the selective institutions that are in our sample where most students are full-time students

9 2002-2003 Title IV/Federal Pell Grant Program End-of-Year Report, Table 2A

${ }^{10}$ Tebbs and Turner (2004) caution that the Pell Grant recipient data refer to students attending an institution anytime during a year, while IPEDs enrollment data refer to a point of time in the fall. Hence, other factors held constant, if turnover of students is high at an institution during the year, this will artificially make the "share" of Pell Grant recipients at the institution appear to be high. We control for this in the empirical work that follows by including institutional fixed effects in our estimation methods.
} 
Table 3 presents information, by year, on the mean ratio of the number of Pell Grant recipients at an institution to the number of full-time undergraduates attending the institution for the 100 institutions in our sample during the 1983 to 2000 period. The column headed "unweighted" presents information on the average percentage across institution, while the column headed "weighted" is a weighted average, with the enrollments used as weights. These data suggest that the percentage of Pell Grant recipients among the undergraduate students at these institutions fluctuated, but gradually increased during the period. ${ }^{11}$

This increase tells us little about the impact of the growth of institutionally funded $N M S$ at these institutions on the number of Pell Grant recipients at the institutions during the period; the share of Pell Grant recipients at these institutions will vary over time as the income distribution of the populations changes, as eligibility rules change, as maximum award levels change and as tuition levels at the institutions change. Hence to analyze the impact of changes in the number of $N M S$ recipients on the number of Pell Grant recipients, we must control for these other factors in our analyses

\section{Analytic Approach}

Our goal is to see how the number of institutionally financed new $N M S$ winners $\left(\mathrm{M}_{\mathrm{t}}\right)$ at an institution influence the number of Pell Grant recipients $\left(\mathrm{P}_{\mathrm{t}}\right)$ at the institution, other factors held constant). A problem that immediately presents itself is that the number of

\footnotetext{
${ }^{11}$ We caution the reader that part-time students attending at least half-time are eligible for Pell Grants. However, the 2002-2003 Title IV/Federal Pell Grant Program End-of-Year Report (table 13) indicates that $86.9 \%$ of the Pell Grant recipients attending public 4-year institutions and $87.8 \%$ of the Pell Grant recipients attending private 4-year institutions were full-time students that year For the institutions in our sample, part-time students represent only 12.6 percent of all students and using total undergraduate students in the denominator of our ratio does not change the trends reported above or any of the econometric results that follow. We also should caution that only U.S. Citizens and permanent residents are eligible for Pell Grants. Thus if an institution enrolls a high fraction of foreign students, its Pell Grant ratio will, other factors held constant, appear to be low.
} 
$N M S$ winners refers to entering first-year students, while the number of Pell Grant recipients refers to all enrolled undergraduates. If we had data on the number of Pell Grant recipients that were first-year students at an institution, we would use this information and information on the number of new first-year students at the institution to construct the fraction of first-year students that were Pell Grant recipients at the institution and then estimate how changes in the number of $N M S$ winners affects that ratio. However, Pell Grant data is not available at the institutional level by the year that the student is enrolled in college.

A solution to this problem is possible if we make some very strong and admittedly unrealistic assumptions. Specifically, if one is willing to assume for simplicity that all students at the institution enter as first-year students, that no students drop out before graduation, that students' Pell Grant eligibility does not change during the years that they are enrolled in college and that all students who graduate do so in four years, then the following relationship holds (1) $\mathrm{P}_{\mathrm{it}}=\mathrm{p}_{\mathrm{it}}+\mathrm{p}_{\mathrm{it}-1}+\mathrm{p}_{\mathrm{it}-2}+\mathrm{p}_{\mathrm{it}-3 .}$

Here $p_{i t}$ is the number of new first-year Pell Grant recipients that enroll at the institution in year t. Put simply, the total number of Pell Grant recipients at the institution in year $t$ is the sum of the number of new first-year Pell grant recipients that enrolled at the institution in year $t$ and in each of the three preceding years. If one writes down the equivalent expression for $\mathrm{P}_{\mathrm{it}-1}$ and then subtracts this from $\mathrm{P}_{\mathrm{it}}$, one finds that (2) $\mathrm{P}_{\mathrm{it}}-\mathrm{P}_{\mathrm{it}-1}=\mathrm{p}_{\mathrm{it}}-\mathrm{p}_{\mathrm{it}-4}$

Given the assumptions that we have made, the difference between the number of Pell Grant recipients at an institution in year $\mathrm{t}$ and year $\mathrm{t}-1$ is the difference between the 
numbers of first-year Pell Grant recipients in year $t$ and year $t-4$. Hence if we want to estimate how changes in the number of $N M S$ influence changes in the number of Pell Grant recipients at the institution between years $t$ and $t-1$, the correct change in the number of $N M S$ winners to use is the difference between $\mathrm{M}_{\mathrm{t}}$ and $\mathrm{M}_{\mathrm{t}-4}$. So the dependent variable in our econometric analyses will be based upon one year changes in the numbers of Pell Grant recipients, while our explanatory variable will be based upon four year changes in the number of institutionally funded $N M S$ winners.

Our empirical approach is to use our institutional level panel data to estimate equations in which the one year change in the ratio of the number of Pell Grant recipients to the number of full-time undergraduate students at an institutions is specified to be a linear function of the four year change in the share of first-year full-time undergraduate students that receive institutionally financed $N M S$ awards at the institution, institutional fixed effects, year fixed effects, and a random error term.

(3) $\left(\mathrm{P}_{\mathrm{it}} / \mathrm{F}_{\mathrm{it}}\right)-\left(\mathrm{P}_{\mathrm{it}-1} / \mathrm{F}_{\mathrm{it}-1}\right)=\mathrm{a}_{0}+\mathrm{a}_{1}\left(\left(\mathrm{M}_{\mathrm{it}} / \mathrm{N}_{\mathrm{it}}\right)-\left(\mathrm{M}_{\mathrm{it}-4} / \mathrm{N}_{\mathrm{it}-4}\right)\right)+\mathrm{u}_{\mathrm{i}}+\mathrm{v}_{\mathrm{t}}+\mathrm{e}_{\mathrm{it}}$

Here $F_{\text {it }}$ is the number of full-time enrolled undergraduates at institution $\mathrm{i}$ in year $t, N_{i t}$ is the number of full-time first-year students enrolled at institution $i$ in year $t$, the $a_{j}$ are parameters, the $\mathrm{u}_{\mathrm{i}}$ are the institutional fixed effects, the $\mathrm{v}_{\mathrm{t}}$ are the year fixed effects and the $\mathrm{e}_{\mathrm{it}}$ is a random error term. The institutional fixed effects are included in the model to control for institution specific factors other than changes in the number of $N M S$ award winners that might affect the change in the share of Pell Grant recipients at an institution. The year fixed effects are included to control for changes in national factors that might affect the share of Pell Grant recipients over time; these factors include changes in the 
distribution of family income of college-age students, changes in Pell Grant eligibility and generosity rules, and changes in Pell Grant funding levels.

The Pell Grant and NMS variables have each been deflated by a relevant size variable (total full-time undergraduate students or total full-time first year students) to control for changes in the size of each institution over time. Because part-time students enrolled for at least one-half of a normal full-time load are eligible to receive Pell Grants, in the empirical work in the next section, we also experiment with deflating the Pell grant and $N M S$ variables by the total number of undergraduate students and the total number of first-year students at the institution.

Finally, we should note that our use of the one year change in the number of Pell Grant recipients at institution to measure the four year change in the number of freshman Pell Grant recipients at an institution is likely to be subject to substantial measurement error because of the set of strict assumptions that we had to make to derive this equivalence. However, if the measurement error is random, it will serve only to increase the imprecision of our estimates; it will not bias the coefficient of the $N M S$ variable.

\section{Empirical Findings}

Table 4 summarizes our initial estimates of equation (3). The coefficients in the table are estimates of the parameter $a_{1}$ that come from four different model specifications. The first is based upon the total number of new $N M S$ recipients at an institution, regardless of the source of funding. The second is based upon the number of institutionally funded $N M S$ recipients. The third is based upon the number of $N M S$ recipients at the institution that are not funded by the institution. The final specification includes both the number of institutionally funded $N M S$ and the number of $N M S$ recipients funded in other ways as 
explanatory variables. For each specification, we present estimated coefficients for models that excluded and included year fixed effects; the estimates are not very sensitive to these variables. The panel used in this estimation makes use of four years of $N M S$ recipient data - 1983,1987, 1991 and 1995, so we have three change observations for each institution in the sample. ${ }^{12}$

The coefficients in row 1 suggest that increasing the ratio of new $N M S$ award winners, irrespective of source of funding, at an institution to the size of the institution's first-year full-time student body reduces the ratio of the institution's number of Pell Grant recipients to its full-time undergraduate enrollments. If the sizes of the institution's firstyear full-time student body and its full-time undergraduate enrollments remain constant, the interpretation of the coefficients are that an increase in NMS awards of ten at an institution is associated with a reduction in the number of Pell Grant recipients at the institution of about two.

When we restrict our attention to the number of institutional funded $N M S$, the magnitude of the reduction is doubled to a reduction of four Pell Grant recipients for every ten additional institutionally funded $N M S$ award winners, again holding constant full-time freshman and full-time total undergraduate enrollment levels. Indeed, when we restrict our attention to $N M S$ winners not funded by the institution in row 3, an increase in the number of these winners at an institution has no statistically significant effect on the number of Pell Grant recipients at the institution. This finding is confirmed in the coefficients from the last model (row 4); when both the number of institutionally

\footnotetext{
${ }^{12}$ The 2003 data could not be used because IPEDs data are not yet available for full-time first year students and total full time undergraduate enrollment for 2002 or 2003. We exclude the 1999 data because IPED enrollment data were not collected for that year. However, we report below our efforts to include data for 1999 by using the average of the institution's enrollment in 1998 and 2000 as a proxy for its 1999 enrollment level.
} 
financed and other $N M S$ award recipients are included as explanatory variables only increases in the former have a negative effect on the number of Pell Grant recipients at the institution. Put simply, in our sample of institutions, other factors held constant including the total full-time undergraduate and first-year enrollment levels, offering more institutionally funded NMS awards is associated with fewer Pell Grant recipients attending the institution and the magnitude of the reduction is roughly four less Pell Grant recipients for each ten additional institutional NMS recipients enrolled at the institution.

Table 5 presents estimates of coefficients from the models in table 4 that included year fixed effects, in which the models were estimated for various subgroups of our sample. In particular, we present estimates for the entire sample (the same as in table 4), for the top 80 institutions in terms of the number of Pell Grant recipients in 2003, for the top 60 institutions, for the top 40 institutions, for the top 20 institutions and for the top 10 institutions. These analyses confirm that only the institutionally financed and awarded $N M S$ adversely influence the number of Pell Grant recipients at an institution. However, the magnitude of this displacement effect varies across institution. In particular, the magnitude of the displacement effect increases as we move from the top 100 institutions, to the top 80 , down to the top 10 (in terms of total number of Pell Grant recipients in 2003). It is at the institutions with the largest number of Pell Grant recipients that the displacement of Pell Grant recipients by institutionally funded NMS recipients is the largest. Indeed, we cannot reject the hypothesis that, other factors held constant, at the top 10 institutions, every additional institutionally financed $N M S$ recipient that attends the 
institution is associated with a reduction of one Pell Grant recipient attending the institution. ${ }^{13}$

Several extensions of our analyses warrant brief mention. First, we replicated the analyses found in table 5 separately for public and private institutions. The pattern of displacement effects for the privates was very similar to those for the entire sample; the coefficients of the institutional $N M S$ variable were indistinguishable for each subgroup between private institutions and for the overall sample (reported in table 5). In contrast, the displacement effects of increasing institutional $N M S$ awards at public institutions were not significantly different from zero when we used the top 80 and top 100 samples. This says that at those public institutions which lie below number 60 in terms of total NMS recipients in 2003, we find no evidence of a displacement of Pell Grant recipients by institutionally funded $N M S$ recipients.

Second, we replicated the analyses found in table 5, adding data for 1999 to the sample. Because 1999 enrollment data was not collected by IPEDs, this required us to estimate the 1999 number of full-time first year students for each institution by the average of the 1998 and 2000 values of this variable for each institution. We found that even with the measurement error that is induced by doing this, our estimates of the displacement effects of increasing the number of institutionally sponsored NMS recipients at an institution on the number of Pell Grant recipients at the institution were roughly of the same order of magnitude as those found in table 5 .

Third, part-time students attending an institution at least half-time are eligible to receive Pell Grants. While we do not know the number of part-time students at each

\footnotetext{
${ }^{13}$ Four of the top 10 institutions are selective private universities that have no institutionally financed NMS recipients. Four of the other six are flagship public universities (appendix table A)
} 
institution each year that meet this criteria, we experimented with either including parttime students in the total enrollment figures that are in the denominator of the dependent variable in equation (3), including part-time first-year students in the total first-year enrollment figure that is in the denominator of the explanatory variables in equation (3), or doing both simultaneously. None of these changes substantially affected the findings that we have reported so far.

Finally, we divided our sample into institutions that experienced increases in total full-time enrollments during both the 1987-1991 and 1991-1995 periods and all other institutions. We estimated variants of the models that underlie table 4 for both groups. We found that a strong statistically significant negative relationship exists between the change in the ratio of institutionally funded $N M S$ to the number of full-time first-year students and the change in the ratio of the number of Pell Grant recipients to the total full-time undergraduates enrolled at the institution existed only at the "growing" institutions. Thus, the displacement of Pell Grant recipients by institutionally awarded $N M S$ recipients in our sample appears to occur only at institutions with growing enrollments and largely reflects a change in the share of Pell Grant recipients in the student body, not always an absolute decline in the number of Pell grant recipients.

\section{Concluding Remarks}

Our study has provided the evidence that, other factors held constant, an increase in the share of institutionally funded $N M S$ students in a college or university's first-year class is associated with a reduction in the share of Pell Grant recipients among the undergraduate student body at the institution. The magnitude of this displacement effect is largest at the institutions in our sample that enroll the greatest number of NMS students 
and it occurs primarily in institutions whose enrollment is growing. We stress that we have observed this displacement effect, as we expected, only for institutionally sponsored $N M S$; we do not observe any displacement of Pell Grant recipients if an institution is able to increase the number of $N M S C$ or company sponsored recipients that it enrolls. Those $N M S$ winners, who receive their awards regardless of at which institution they choose to enroll, do not appear to displace any student from lower-income families when they enroll at an institution.

While our research has focused only on $N M S$ awards, it highlights the tradeoff that may exist more broadly between using institutional grant aid to craft a more selective student body than would otherwise occur and using institutional grant aid to attract more students from families from the lower tail of the family income distribution. If selective institutions, especially public ones, are committed to serving students from all socioeconomic backgrounds, these institutions must track the share of their students that receive Pell grants and focus on socioeconomic diversity as well as on student selectivity as goals. Absent concerted efforts by these institutions to increase the representation of students from lower and lower middle income families in their student ranks, current inequalities in the distribution of students attending these institutions by family income class are likely to persist or worsen over time. ${ }^{14}$

\footnotetext{
${ }^{14}$ William G. Bowen, Martin A Kurzweil and Eugene M. Pichler (2005)
} 


\section{References}

Christopher Avery and Caroline M. Hoxby, "Do and Should Financial Aid Decisions Affect Students' College Choices?" in Caroline Hoxby ed. College Choices; The New Economics of Choosing, Attending and Completing College (Chicago IL: University of Chicago Press, 2004)

William G. Bowen, Martin A. Kurzweil, and Eugene M. Tobin, Equity and Excellence in American Higher Education (Charlottesville VA: University Press of Virginia, 2005)

Elizabeth A. Duffy and Idana Goldberg, Crafting a Class: College Admissions and Financial Aid, 1955-1994 (Princeton NJ: Princeton University Press, 1998)

Ronald G. Ehrenberg, "Method or Madness? Inside the USNWR College Rankings", Journal of College Admissions (forthcoming)

Michael S. McPherson and Morton O. Schapiro, The Student Aid Game (Princeton NJ: Princeton University Press, 1998)

Michael S. McPherson and Morton O. Schapiro, “The Blurring Line Between Merit and Need in Financial Aid", Change 34 (March/April 2002): 38-46

Neil S. Seftor and Sarah E. Turner, "Back to School: Federal Student Aid Policy and Adult College Enrollment", Journal of Human Resources 37 (Spring 2002): 336-352 Jeffrey Tebbs and Sarah Turner, "College Education for Low Income Students: A Caution on the Use of Data on Pell Grant Recipients" (draft paper, University of Virginia, September 2004)

Trends in Student Aid 2004, (Washington DC: The College Board, 2004) 
2002-2003 Title IV/Federal Pell Grant Program End-of-Year Report (available at http:///www.ed.gov/finaid/prof/resources/data/pell0203/ope.html ) 


\section{Table 1}

Number of Total and Institution-Funded National Merit Scholarship Students ${ }^{\mathrm{a}}$

\begin{tabular}{|c|c|c|c|c|c|c|}
\hline \multirow[b]{2}{*}{ year } & \multicolumn{3}{|c|}{ All Institutions } & \multicolumn{3}{|c|}{ Top 100 Institutions ${ }^{\mathrm{b}}$} \\
\hline & Total & $\begin{array}{l}\text { Institution } \\
\text { Funded }\end{array}$ & $\begin{array}{c}\text { Percent } \\
\text { Institution } \\
\text { Funded }\end{array}$ & Total & $\begin{array}{c}\text { Institution } \\
\text { Funded }\end{array}$ & $\begin{array}{c}\text { Percent } \\
\text { Institution } \\
\text { Funded }\end{array}$ \\
\hline 1983 & 5566 & 2,382 & 42.8 & 4330 & 1796 & 41.5 \\
\hline 1987 & 6127 & 2,976 & 48.6 & 4844 & 2214 & 45.7 \\
\hline 1991 & 6552 & 3,463 & 52.9 & 4982 & 2489 & 50.0 \\
\hline 1995 & 7030 & 3,975 & 56.5 & 5496 & 2951 & 53.7 \\
\hline 1999 & 8081 & 4,582 & 56.7 & 6594 & 3660 & 55.5 \\
\hline 2003 & 8254 & 4,670 & 56.6 & 6965 & 3856 & 55.4 \\
\hline
\end{tabular}

${ }^{a}$ Data on the number of National Merit Scholarship students by institution are provided by the National Merit Scholarship Corporation. A complete list of these institutions was made available to us for 1983, 1984, 1985, 1986, 1987, 1991, 1995, 1999, and 2003. The Chronicle of Higher Education publishes the top X institutions (where X varies across years from 30 to 100) that enroll the most National Merit Scholarship students in many years. Because of the changing coverage, we have not used the Chronicle's data.

${ }^{\mathrm{b}}$ The top 100 institutions are determined by the total number of merit NMS students in an institution in 2003; these institutions are not necessarily the top 100 in earlier years. These institutions enroll about $80 \%$ of all $N M S$ (ranging from $78 \%$ in 1983 to $84 \%$ in 2003 ). 
Table 2

Distribution of National Merit Scholarship Students at the Top 100 Institutions: By Source of Sponsorship

\begin{tabular}{|c|c|c|c|c|c|c|c|c|c|c|c|c|}
\hline \multirow[b]{2}{*}{ year } & \multicolumn{4}{|c|}{ All } & \multicolumn{4}{|c|}{ Institution Funded } & \multicolumn{4}{|c|}{ Non-Institution Funded } \\
\hline & $25^{\text {th }}$ & $50^{\text {th }}$ & $75^{\text {th }}$ & mean & $25^{\text {th }}$ & $50^{\text {th }}$ & $75^{\text {th }}$ & mean & $25^{\text {th }}$ & $50^{\text {th }}$ & $75^{\text {th }}$ & mean \\
\hline 198384 & 12 & 24 & 47 & 42 & 0 & 5 & 20 & 17 & 5 & 10 & 29 & 25 \\
\hline 198788 & 20 & 30 & 52 & 47 & 0 & 14 & 26 & 21 & 5 & 9 & 29 & 26 \\
\hline 199192 & 20 & 32 & 55 & 48 & 0 & 16 & 34 & 24 & 6 & 12 & 24 & 24 \\
\hline 199596 & 23 & 36 & 57 & 53 & 0 & 20 & 36 & 29 & 5 & 12 & 23 & 25 \\
\hline 199900 & 28 & 41 & 85 & 64 & 6 & 25 & 41 & 36 & 6 & 15 & 31 & 28 \\
\hline 200304 & 29 & 44 & 77 & 68 & 12 & 26 & 40 & 37 & 7 & 14 & 33 & 30 \\
\hline
\end{tabular}


Table 3

Percentage of Full-Time Undergraduate Students

That are Pell Grant Recipients at the Top 100 Institutions $^{\text {a }}$

(as defined in table 1)

\begin{tabular}{lrr}
\hline year & Unweighted & Weighted \\
\hline 1983 & 18.60 & 21.16 \\
1984 & 18.32 & 21.02 \\
1985 & 18.23 & 21.12 \\
1986 & 15.94 & 18.67 \\
1987 & 16.58 & 19.77 \\
1988 & 19.50 & 23.14 \\
1989 & 19.75 & 23.42 \\
1990 & 19.34 & 23.21 \\
1991 & 21.30 & 25.56 \\
1992 & 22.64 & 27.32 \\
1993 & 21.98 & 25.89 \\
1994 & 22.05 & 26.01 \\
1995 & 21.71 & 25.60 \\
1996 & 21.72 & 25.75 \\
1997 & 21.72 & 25.79 \\
1998 & 21.95 & 26.24 \\
$1999^{b}$ & 20.05 & 23.97 \\
2000 & 19.22 & 23.19 \\
\hline
\end{tabular}

${ }^{\mathrm{a}}$ The Pell Grant data are from the Federal Pell Grant Program administrated by the Department of Education. We received data from the Department of Education for academic years 1983-84 to 2003-04 on the number of students receiving Pell Grants and total amount of Pell Grants received at each Title IV institution each year during the period. Data on the number of full-time undergraduates enrolled at each institution and the number of full-time first-time freshman at each institution are from Webcaspar (http://caspar.nsf.gov). The percentage of Pell Grant recipients at an institution in a year is 100 times the number of Pell Grant recipients at the institution in the year divided by the number of full-time undergraduates enrolled at the institution in a year.

${ }^{\mathrm{b}}$ Enrollment data were not provided by Webcaspar for 1999, so we used the average of the 1998 and 1999 figures for that year. 


\section{Table 4}

Estimates of the Impact of a Change in the Share of Freshman at an Institution that are National Merit Scholarship Winners on the Change in the Share of Undergraduates at the Institution that Receive Pell Grants: Fixed Effects Models (t statistics)

\begin{tabular}{|c|c|c|}
\hline & \multicolumn{2}{|c|}{$\begin{array}{l}\text { Share of Pell Grant Recipients } \\
\qquad \text { Pell }_{t}-\text { Pell }_{t-1}\end{array}$} \\
\hline (1)Share of Total Merit $t$ - Merit $t_{t-4}$ & $-0.200(-2.35)$ & $-0.171(-2.16)$ \\
\hline (2)Share of Inst. Merit $t_{t}-$ Merit $_{t-4}$ & $-0.415(-3.16)$ & $-0.409(-3.38)$ \\
\hline (3)Share of Non-inst. Merit ${ }_{t}-$ Merit $_{t-4}$ & $-0.070(-0.52)$ & $-0.004(-0.03)$ \\
\hline (4)Share of Inst. Merit ${ }_{t}-$ Merit $_{t-4}$ & $-0.418(-3.12)$ & $-0.427(-3.44)$ \\
\hline Share of Non-inst. Merit ${ }_{t}-$ Merit $_{t-4}$ & $0.018(0.14)$ & $0.086(0.69)$ \\
\hline Year Fixed Effects Included & No & Yes \\
\hline
\end{tabular}


Table 5

Estimates of the Impact of a Change in the Share of Freshman at an Institution that are National Merit Scholarship Winners on the Change in the Share of Undergraduates at the Institution that Receive Pell Grants: Fixed Effects Models Estimated Separately For Different Samples ${ }^{\text {a }}$ (t statistics)

\begin{tabular}{|c|c|c|c|}
\hline & \multicolumn{3}{|c|}{$\begin{array}{c}\text { Share of Pell Grant Recipients } \\
\text { Pell }_{t}-\text { Pell }_{t-1}\end{array}$} \\
\hline & Top 100 & Top 80 & Top 60 \\
\hline (1)Share of Total Merit $t_{t}-$ Merit $_{t-4}$ & $-0.171(-2.16)$ & $-0.176(-1.91)$ & $-0.172(-1.63)$ \\
\hline (2)Share of Inst. Merit $_{t}-$ Merit $_{t-4}$ & $-0.409(-3.38)$ & $-0.420(-3.00)$ & $-0.436(-2.69)$ \\
\hline $\begin{array}{l}\text { (3)Share of Non-inst. Merit }{ }_{t} \text { - } \\
\text { Merit }_{t-4}\end{array}$ & $-0.004(-0.03)$ & $-0.001(-0.01)$ & $0.012(0.07)$ \\
\hline $\begin{array}{l}\text { (4)Share of Inst. Merit }{ }_{t}-\text { Merit }_{t-4} \\
\text { Share of Non-inst. Merit }- \text { Merit }_{t-4}\end{array}$ & $\begin{array}{c}-0.427(-3.44) \\
0.086(0.69)\end{array}$ & $\begin{array}{c}-0.442(-3.08) \\
0.102(0.69)\end{array}$ & $\begin{array}{c}-0.465(-2.78) \\
0.122(0.73)\end{array}$ \\
\hline Year Fixed Effects & Yes & Yes & Yes \\
\hline
\end{tabular}

Share of Pell Grant Recipients:

Pell $_{t}-$ Pell $_{t-1}$

\begin{tabular}{|c|c|c|c|}
\hline & Top 40 & Top 20 & Top 10 \\
\hline (1)Share of Total Merit ${ }_{t}-$ Merit $_{t-4}$ & $-0.288(-2.50)$ & $-0.397(-2.14)$ & $-0.699(-2.74)$ \\
\hline (2)Share of Inst. Merit I $_{t}$ Merit $_{t-4}$ & $-0.551(-3.25)$ & $-0.824(-2.93)$ & $-1.471(-4.06)$ \\
\hline $\begin{array}{l}\text { (3)Share of Non-inst. Merit }{ }_{t} \text { - } \\
\text { Merit }_{t-4}\end{array}$ & $-0.130(-0.65)$ & $-0.209(-0.62)$ & $-0.392(-0.85)$ \\
\hline $\begin{array}{l}\text { (4)Share of Inst. Merit } t \text { - Merit } \text { Met }_{t} \\
\text { Share of Non-inst. Merit }{ }_{t}-\text { Merit }_{t-4}\end{array}$ & $\begin{array}{c}-0.558(-3.16) \\
0.031(0.16)\end{array}$ & $\begin{array}{c}-0.867(-2.84) \\
0.129(0.39)\end{array}$ & $\begin{array}{l}-1.465(-3.77) \\
-0.020(-0.06)\end{array}$ \\
\hline Year Fixed Effects & Yes & Yes & Yes \\
\hline
\end{tabular}

${ }^{\text {a } U s i n g ~ p a n e l ~ d a t a ~ f o r ~ 1983, ~ 1987, ~} 1991$ and 1995 


\section{Appendix \\ Colleges and Universities with the Most Freshman NMS in 2003}

\begin{tabular}{|c|c|c|c|}
\hline Rank & Institution & Total NMS & $\begin{array}{l}\text { onsored by } \\
\text { Institution }\end{array}$ \\
\hline 1 & Harvard University & 378 & 0 \\
\hline 2 & University of Texas at Austin & 258 & 201 \\
\hline 3 & Yale University & 228 & 0 \\
\hline 4 & University of Florida & 224 & 185 \\
\hline 5 & Stanford University & 217 & 0 \\
\hline 6 & University of Chicago & 182 & 148 \\
\hline 7 & Arizona State University & 176 & 153 \\
\hline 8 & Rice University & 173 & 102 \\
\hline 9 & University of Oklahoma & 170 & 146 \\
\hline 10 & Princeton University & 165 & 0 \\
\hline 11 & Washington University in St. Louis & 162 & 125 \\
\hline 12 & University of Southern California & 161 & 132 \\
\hline 13 & Massachusetts Inst. of Technology & 151 & 0 \\
\hline 14 & University of North Carolina at Chapel Hill & 143 & 117 \\
\hline 14 & Vanderbilt University & 143 & 103 \\
\hline 16 & Brigham Young University & 140 & 97 \\
\hline 17 & Texas A\&M University & 137 & 103 \\
\hline 18 & New York University & 136 & 115 \\
\hline 19 & University of California at Los Angeles & 125 & 94 \\
\hline 20 & Duke University & 103 & 0 \\
\hline 21 & University of Pennsylvania & 101 & 0 \\
\hline 22 & Northwestern University & 96 & 53 \\
\hline 23 & Ohio State University & 93 & 77 \\
\hline 23 & Purdue University & 93 & 75 \\
\hline 25 & Carleton College & 79 & 62 \\
\hline 26 & Georgia Institute of Technology & 77 & 62 \\
\hline 27 & University of Georgia & 75 & 59 \\
\hline 28 & Iowa State University & 69 & 55 \\
\hline 29 & University of California at Berkeley & 67 & 0 \\
\hline 30 & Michigan State University & 60 & 46 \\
\hline 31 & University of Arizona & 59 & 47 \\
\hline 31 & University of Michigan at Ann Arbor & 59 & 0 \\
\hline 33 & University of California at San Diego & 56 & 38 \\
\hline 34 & Boston University & 54 & 39 \\
\hline 35 & Case Western Reserve University & 53 & 28 \\
\hline 36 & University of Nebraska at Lincoln & 52 & 40 \\
\hline 37 & Macalaster College & 51 & 48 \\
\hline 38 & California Institute of Technology & 50 & 0 \\
\hline 38 & University of Kansas & 50 & 40 \\
\hline 40 & Johns Hopkins University & 49 & 32 \\
\hline 40 & University of Tulsa & 49 & 38 \\
\hline 40 & University of Maryland at College Park & 49 & 34 \\
\hline 43 & Brown University & 47 & 0 \\
\hline
\end{tabular}




\begin{tabular}{|c|c|c|c|}
\hline 43 & Columbia University & 47 & 0 \\
\hline 45 & Oberlin College & 46 & 38 \\
\hline 45 & Tulane University & 46 & 36 \\
\hline 47 & Dartmouth College & 45 & 0 \\
\hline 47 & University of Kentucky & 45 & 33 \\
\hline 47 & University of South Carolina at Columbia & 45 & 34 \\
\hline 47 & Wheaton College (Ill.) & 45 & 40 \\
\hline 51 & University of Notre Dame & 44 & 0 \\
\hline 51 & University of Washington & 44 & 26 \\
\hline 53 & Harvey Mudd College & 43 & 32 \\
\hline 54 & Kenyon College & 41 & 33 \\
\hline 54 & Tufts University & 41 & 37 \\
\hline 56 & Baylor University & 40 & 31 \\
\hline 56 & Grinnell College & 40 & 35 \\
\hline 56 & University of Arkansas at Fayetteville & 40 & 33 \\
\hline 56 & University of Minnesota-Twin Cities & 40 & 26 \\
\hline 60 & Cornell University & 38 & 0 \\
\hline 60 & Emory University & 38 & 27 \\
\hline 62 & George Washington University & 37 & 32 \\
\hline 62 & Georgetown University & 37 & 0 \\
\hline 62 & St. Olaf College & 37 & 31 \\
\hline 65 & University of Alabama at Tuscaloosa & 35 & 28 \\
\hline 66 & Rose-Hulman Institute of Technology & 34 & 24 \\
\hline 67 & Clemson University & 33 & 26 \\
\hline 67 & Miami University (Ohio) & 33 & 26 \\
\hline 67 & University of Central Florida & 33 & 28 \\
\hline 67 & University of Illinois at Urbana-Champaign & 33 & 0 \\
\hline 67 & University of Virginia & 33 & 0 \\
\hline 72 & Louisiana State University at Baton Rouge & 32 & 25 \\
\hline 72 & University of Mississippi & 32 & 24 \\
\hline 74 & Brandeis University & 31 & 24 \\
\hline 74 & Furman University & 31 & 29 \\
\hline 74 & University of Miami & 31 & 22 \\
\hline 74 & University of Texas at Dallas & 31 & 28 \\
\hline 78 & Carnegie Mellon University & 29 & 0 \\
\hline 78 & North Carolina State University & 29 & 21 \\
\hline 80 & Auburn University & 28 & 20 \\
\hline 80 & University of Wisconsin at Madison & 28 & 4 \\
\hline 82 & University of Houston & 27 & 25 \\
\hline 83 & Williams College & 26 & 0 \\
\hline 84 & Amherst College & 25 & 0 \\
\hline 84 & University of California at Irvine & 25 & 20 \\
\hline 86 & Mississippi State University & 24 & 21 \\
\hline 86 & University of Tennessee at Knoxville & 24 & 20 \\
\hline 88 & Bowdoin College & 23 & 21 \\
\hline 88 & Pomona College & 23 & 6 \\
\hline 88 & University of Iowa & 23 & 19 \\
\hline 88 & University of Utah & 23 & 17 \\
\hline 88 & Washington and Lee University & 23 & 13 \\
\hline 93 & Swarthmore College & 21 & 0 \\
\hline
\end{tabular}




\begin{tabular}{llll}
93 & University of Rochester & 21 & 18 \\
93 & University of South Florida & 21 & 17 \\
93 & Virginia Tech & 21 & 15 \\
97 & Bowling Green State University & 20 & 18 \\
97 & Calvin College & 20 & 17 \\
97 & Kansas State University & 20 & 12 \\
& Pennsylvania State University at University & & \\
97 & Park & 20 & 5 \\
97 & Trinity University (Tex.) & 20 & 17 \\
97 & University of Richmond & 20 & 12 \\
97 & Whitman College & 20 & 16 \\
\hline
\end{tabular}


